\title{
Concrete using sawdust as partial replacement of sand : Is it strong and does not endanger health?
}

\author{
Nurul Huda Suliman ${ }^{1}$, Amir Atif Abdul Razak ${ }^{2}$, Hazrina Mansor ${ }^{1}$, Anizahyati Alisibramulisi ${ }^{1}$, Norliyati Mohd Amin ${ }^{1}$, \\ ${ }^{1}$ Faculty of Civil Engineering, UiTM Shah Alam, Malaysia. \\ ${ }^{2}$ RJA Consultant, Damansara, Kuala Lumpur, Malaysia.
}

\begin{abstract}
This study was conducted to investigate the effectiveness of concrete using sawdust to partially replace the river sand which could reduce both environmental problems and construction cost. In this study, sawdust concrete has been produced where the river sand is replaced with sawdust by $5 \%, 10 \%$ and $15 \%$ of the total sand volume. Both wet concrete and hardened concrete (cubes specimens) were tested through material testing and cube testing to obtain the most optimum sawdust concrete design. In addition, specimens have also been tested in environmental laboratory to identify the extent of hazardous use of sawdust to consumer health. This is because the dust used is the waste taken from the unknown root of the level of cleanliness. The result shows that the most optimum design for producing sawdust concrete is that with $10 \%$ replacement of river sand. The result is based on the compressive strength obtained. The results of environmental study also show that this sawdust concrete is free from any harmful to health contaminants.
\end{abstract}

\section{Introduction}

Sustainable development is a very important agenda in this century. This is where the world needs balance in maintaining resources, energy and resolving environmental problems. For example, the use of sand in the production of glass, electronics and concretes causing scarcity of sand is growing. In addition to causing eco-system disturbance, the shortage of sand has turned sand from local product into expensive commodity [1][2][3]. Therefore, in this study, sawdust was used partially replacement for sand in concrete production. The application of sawdust will reduce the usage of sand which bring the fact that it also ecofriendly and economical than conventional concrete.

The study on replacement of sand with sawdust in concrete perhaps can give positive outcomes. The significance of sawdust concrete production is to reduce the sawdust waste that could save the environment for a long term run. This is because almost all sawmill dumped the sawdust at landfill which causing the landfill to pile up and increased its volume day by day.

Another significance of this study is reducing the sand usage in concrete mix which eventually reduce the construction cost. Besides, when the usage of sand is reduced, the overall cost of construction also can be deducted as sawdust can be obtained cheaply at sawmill or sometimes with cost-free.

The use of sawdust in concrete production is doubtful because of its easy to decompose properties. However, there have been many studies conducted to test the properties and abilities of this sawdust for use in concrete production. The results of the study have shown that sawdust has unique characteristics and is competitive with other building materials [4].

\subsection{Sawdust Production}

Sawdust is a waste composed of fine particles of wood from different species and sources. In 2016, RM678.2 million has been invested in this wood-based industry, which become one of major revenue contributors to the Malaysia economy [5]. As the $8^{\text {th }}$ largest exporter of tropical timber for sawn timber, panel product, builders' joinery and carpentry, mouldings and furniture/furniture parts, Muar Furniture Park has been stablished by the government to enhance the wood industry. It is comprising houses companies, innovation and training centres. Therefore, the total export of RM53 billion and RM16 billion for wood products and furniture, respectively can be achieved by 2020 which one of the national aim under National Timber Industry Policy (NATIP) [6].

With the increment of export revenue in wood industry, wood waste has also been generated largely. In 2010, it was estimated that $4.09 \times 10^{6} \mathrm{~m}^{3}$ of wood waste was produced which $3.4 \times 10^{6} \mathrm{~m}^{3}$ of them have been used for other purposes. The rest $1.5 \times 10^{6} \mathrm{~m}^{3}$ of wood waste has been dumped at the landfill [7]. In order to face the increase in volume in timber waste from the timber industry, the use of sawdust waste as a building material has been created as a continuation to ensure the balance of industrial growth with the well-being of the people and the environment as shown in Figure 1 [6].

\footnotetext{
* Corresponding author: nurul_huda@salam.uitm.edu.my
} 


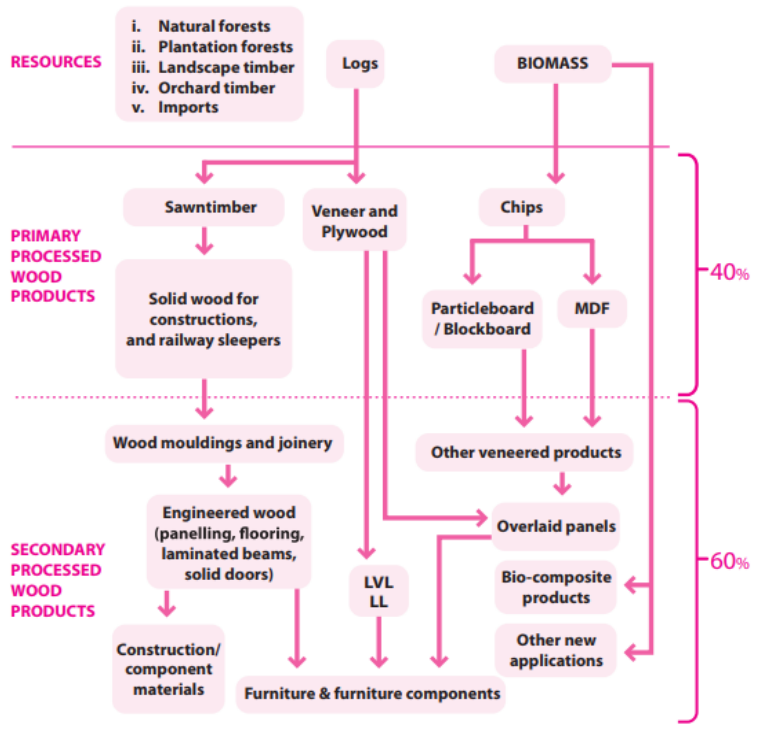

Fig. 1. Recommended future structure of the timber industry [6]

\subsection{Mechanical properties of sawdust}

Knowledge of mechanical properties of sawdust is necessary for design of concrete containing sawdust as sand replacement. The increase in moisture content will increase the pour and consolidation density, while the modulus of elasticity of sawdust is decrease. Sawdust also found as strong material of worse flowability. Angle of internal friction for sawdust also strong negative correlation with moisture content. However, it has no correlation of cohesion versus moisture content, while strong correlation between cohesion and consolidation stress. [8].

\subsection{Comparison between sand and sawdust}

Sand is a loose granular material which available in beaches, riverbeds and deserts of the world. It composed of different materials which depending on its location and also various colors from white, black and also pink. The general component of sand is silicon dioxide which is in form of quartz [9]. The earth's land is made up from various types of rocks and minerals which include quartz, feldspar and mica. While, sawdust is composed of fine particles of wood.

There are several similarities between sawdust and sand in terms of density and particle sizes. The density of sawdust ranging from $650 \mathrm{~kg} / \mathrm{m}^{3}$ to $1650 \mathrm{~kg} / \mathrm{m}^{3}$ while the density of sand is from $1500 \mathrm{~kg} / \mathrm{m}^{3}$ to $1600 \mathrm{~kg} / \mathrm{m}^{3}$ [8][9]. A particle size of sawdust is between 30 to 600 microns while the particle size of sand is 70 to 800 microns [8][9]. Thus, it is quite similar and the usage of sawdust to replace sand is suitable.

\section{Sustainable concrete with sawdust}

The usage of sawdust as a partial replacement of sand must be complete with a research to compare their strength with the conventional concrete. The strength and also the weakness of the concrete should be identified so that the product can be commercialized to a new level. Several studies have been carried out by other researchers on sawdust concrete cubes to identify their mechanical properties and their potential. These studies used different variables in terms of sawdust particle size, sawdust waste source and sawdust quantities to replace sand
$[10][11][12][13]$. Different variables have given different but consistent results. Therefore, this study has used different variables to complement the gap and further reinforce the results obtained from previous researchers. On top of that need, there were four cube specimens size $100 \times 100 \times 100 \mathrm{~mm}$ were produced and tested. The conventional concrete contains $0 \%$ sawdust while other specimens contain $5 \%, 10 \%$ and $15 \%$ of sawdust replacing fine aggregate by volume.

Nevertheless, no studies were conducted to investigate the effect of using sawdust waste from unknown sources to the human health. The invention of construction materials using waste must be conformed in term of the health to the user. Therefore, the properties of concrete leachate taken from curing water must be examine and identify to look at the effect of the product to the environment. Therefore, water quality test has been conducted in this study to measure the condition of the water relative to the requirements of human need and purpose. The chemical indicator or chemical parameter measured are $\mathrm{pH}$, Biological Oxygen Demand (BOD) Dissolved Oxygen (DO) and Chemical Oxygen Demand (COD). These are the most common parameters used to assess water quality relate to health of ecosystems and safety of human contact. The results were compared to the National Water Quality Standards Class II as shown in Table 1 [14].

Table 1: National Water Quality Standards [14].

\begin{tabular}{|c|c|c|c|c|c|c|}
\hline \multirow{2}{*}{ Parameter } & \multirow{2}{*}{ Unit } & \multicolumn{5}{|c|}{ CLASS } \\
\cline { 3 - 7 } & & I & II & III & IV & V \\
\hline $\mathrm{pH}$ & - & $6.5-8.5$ & $6-9$ & $5-9$ & $5-9$ & - \\
\hline $\mathrm{COD}$ & $\mathrm{mg} / 1$ & 10 & 25 & 50 & 100 & $>100$ \\
\hline BOD & $\mathrm{mg} / 1$ & 1 & 3 & 6 & 12 & $>12$ \\
\hline *Class I- & $\begin{array}{l}\text { Conservative of natural environment. } \\
\text { *Class II- Water supply I-Practically no treatment necessary } \\
\text { Fishery-very sensitive aquatic species } \\
\text { Fishery II-sensitive aquatic species } \\
\text { Recreational use body contact }\end{array}$ \\
*Class III- $\begin{array}{l}\text { Water supply III-Extensive treatment required } \\
\text { Fishery III-Common of economic value and tolerant } \\
\text { species; livestock drinking }\end{array}$ \\
*Class IV- Irrigation \\
*Class V- None of the above
\end{tabular}

\section{Preparation of sawdust concrete}

Casting a sawdust concrete cube requires few preparations as a freshly mixed concrete has one quite similar characteristic to liquid which is it occupies space though it is much more viscous and firm. In this research study, 4 types of concrete cube of grade $\mathrm{C} 30$ have been casted. They are concrete cubes contained of $0 \%$, $5 \%, 10 \%$ and $15 \%$ of sawdust as sand replacement.

\subsection{Concrete mix design}

In designing a concrete mix, a specific standard has been referred to DOE standards to ensure the correct ratio or mix so that an economical concrete mix can be produced and it meets its designated strength, durability, consistency and appearance [15] 
Concrete is generally known as a mixture of water, cement and aggregates which comes in two forms that is coarse aggregates of gravels and fine aggregates of sand, so as in this research. Though there are many types of cement in the market, this research specifically uses Ordinary Portland Cement (OPC). Gravel is the conventional aggregate used in general concrete mix. The purpose of using gravel is to aid in strengthening the concrete when adding cement while reducing the use of sand. The sawdust particle was passed $0.6 \mathrm{~mm}$ sieve which is not too fine and almost identical to fine aggregate which is sand that is conforming to British Standard.

The total proportion of concrete materials used to prepare the specimens were $5.95 \mathrm{~kg} / \mathrm{m}^{3}$ of cement, $6.67 \mathrm{~kg} / \mathrm{m}^{3}$ of sand, $16.31 \mathrm{~kg} / \mathrm{m}^{3}$ of gravel and $2.38 \mathrm{~kg} / \mathrm{m}^{3}$ of water.

\subsection{Procurement of sawdust}

The sawdust used in this study was collected from sawmill in Kota Bharu, Kelantan as shown in Figure 2. It was swept off the floor and air dried prior to use. The sawdust was then sieved with $0.6 \mathrm{~mm}$ sieve to imitate the actual size of sand without changing its properties The main species of timber used in this mill are Jati, Getah and Kempas. These species are easily found in Malaysia and Thailand and thus the source is readily available. This sawdust has Specific Gravity of 2.15 [16].

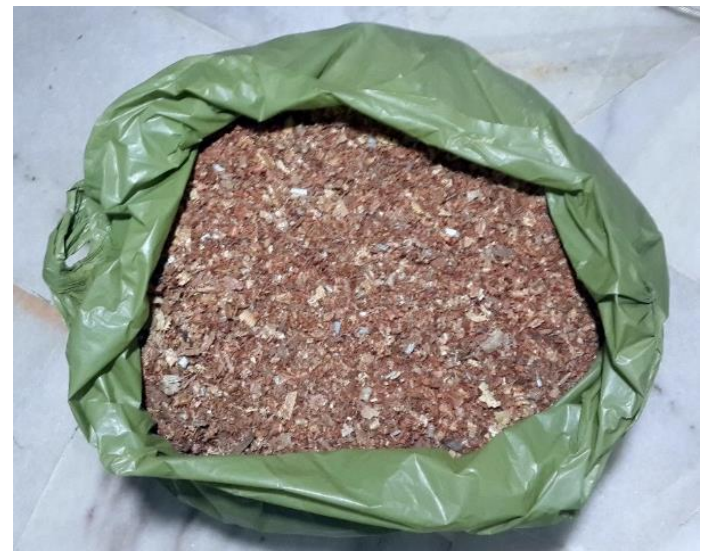

Fig. 2. Untreated sawdust.

\subsection{Specimen casting}

There are four batches of sawdust concrete that are concrete containing $0 \%, 5 \%, 10 \%$ and $15 \%$ of sawdust replacing sand by volume. The effect of sawdust content can affect the mixing efficiency and compressive strength of concrete [17]. It is important to achieve a uniform sawdust concrete mix therefore, all concrete batches have been tested under the slump test. The slump test result are $133 \mathrm{~mm}, 145 \mathrm{~mm}, 162 \mathrm{~mm}$ and $170 \mathrm{~mm}$ for $0 \%, 5 \%, 10 \%$ and $15 \%$ of sawdust concrete respectively.

When proven the credibility of the fresh mix concrete of its workability, all mixed concrete will then have been casted into concrete cube by using steel mould prepared which $100 \times 100 \times 100 \mathrm{~mm}$ dimension. The concrete then poured into the mould by several layers and follows with compaction processes in between those layers to make sure the concrete is well compacted and fill the mould fully in avoiding any defects such as honeycombs and avoid any air traps inside the concrete layers which will eventually reduce the strength and weakens the concrete.
After casting, the concrete cubes then undergo curing process whereby it will be put into curing tank up to 28 days to allow it to hydrate to reach the required strength before further testing.

\section{Experimental Program}

\subsection{Compressive strength test}

As the concrete cube reach its mature age of 28 days after curing process, it will then let dry to proceed into compressive strength test to determine the credibility of the concrete containing sawdust. All specimens also tested at the early hardening stage at 7 and 14 days. Preliminary safety actions also need to be considered in handling machines for specific testing. Beforehand, the machinery and equipment will first be inspected to make sure that no harms will occur.

\subsection{Water quality test}

After curing process of 28 days, water sample from curing tank was taken and bring to environmental laboratory to test the $\mathrm{pH}$, Biological Oxygen Demand (BOD), Dissolved Oxygen (DO) and Chemical Oxygen Demand (COD) content as shown in Figure 3.

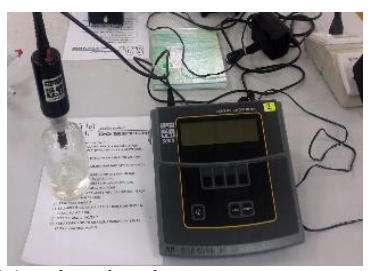

(a) Dissolved oxygen meter

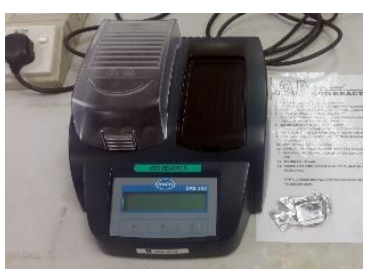

(c) Chemical oxygen demand reactor

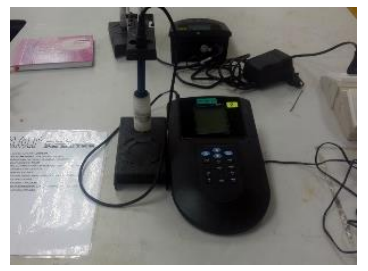

(b) $\mathrm{pH}$ meter

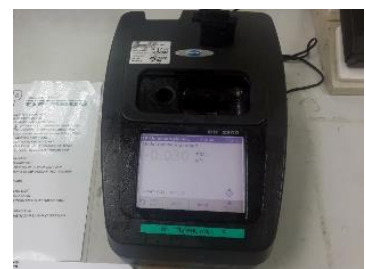

(d) Spectrophotometer
Fig. 3. Equipment used for water quality test

\section{Result and discussion}

\subsection{Compressive strength}

The results of compressive strength were obtained during early, middle and final stage of hardening process to study the effect of sawdust to the compressive strength of concrete during that period. Table 2 shows the compressive strength for all concrete mix types. 
Table 2. Compressive strength of sawdust concrete cube

\begin{tabular}{|c|c|c|c|}
\hline \multirow{2}{*}{ Specimens } & \multicolumn{3}{|c|}{ Compressive strength, MPa } \\
\cline { 2 - 4 } & Day 7 & Day 14 & Day 28 \\
\hline Control & 42.09 & 52.74 & 57.69 \\
\hline $5 \%$ sawdust & 37.15 & 45.33 & 50.06 \\
\hline $\begin{array}{c}10 \% \\
\text { sawdust }\end{array}$ & 35.08 & 42.29 & 41.48 \\
\hline $\begin{array}{c}15 \% \\
\text { sawdust }\end{array}$ & 27.42 & 28.26 & 34.7 \\
\hline
\end{tabular}

All four cube specimens had exceeded the design strength of concerete grade 30 . Therefore, this distinctly shows that the all sawdust mix design are capable as they produced that desired strength. From the experimental result, it is shows that the compressive strength of conventional concrete (control) achieved is $57.69 \mathrm{MPa}$ at 28 days. As the comparison, 5\% sawdust replacement show larger compressive strength in all cases. When the curing time increases, the specimens with $5 \%$ of sawdust performed better and after 28 days of curing time the results are very identical to the control specimen strength with $50.06 \mathrm{MPa}$ which is only $13.22 \%$ difference. While the compressive strength values of $41.48 \mathrm{MPa}$ and $34.7 \mathrm{MPa}$ were found for $10 \%$ and $15 \%$ sawdust replacement respectively.

The pattern of the results from compressive strength test shows that the higher the amount of sawdust has given reverse effect to the concrete bond between cement and sawdust particles. Directly prove that higher amount of sawdust will reduce the strength of concrete [18]. The comparison of the results are shown in Figure 4.

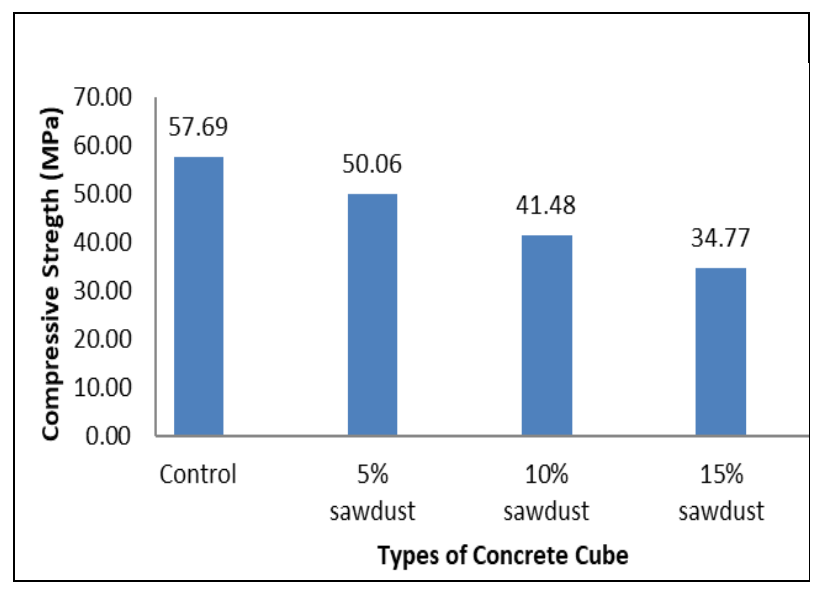

Fig. 4. Compressive strength at 28 days.

\subsection{Water quality indicator}

The results were analyzed and compared with National Water Quality Standard which was obtained from Water Environmental Quality Report 2006 [14]. Based on the standard, there are several classes that were used as a guideline which ranging from Class I until Class V. Table 3 shows the chemical parameter for curing water obtained from the experimental program.
Table 3. Chemical parameter for curing water

\begin{tabular}{|c|c|c|c|c|}
\hline Specimens & $\mathrm{pH}$ value & $\begin{array}{c}\text { Dissolved } \\
\text { Oxygen } \\
\text { (DO), } \\
\mathrm{mg} / \mathrm{L}\end{array}$ & $\begin{array}{c}\text { Biological } \\
\text { Oxygen } \\
\text { Demand } \\
\text { (BOD), } \\
\mathrm{mg} / \mathrm{L}\end{array}$ & $\begin{array}{c}\text { Chemical } \\
\text { Oxygen } \\
\text { Demand } \\
\text { (COD), } \\
\mathrm{mg} / \mathrm{L}\end{array}$ \\
\hline Control & 11.61 & 6.53 & 0.27 & -1 \\
\hline $\begin{array}{c}5 \% \\
\text { sawdust }\end{array}$ & 11.28 & 4.34 & 8.67 & -23 \\
\hline $\begin{array}{c}10 \% \\
\text { sawdust }\end{array}$ & 11.21 & 1.77 & 13.26 & -10 \\
\hline $\begin{array}{c}15 \% \\
\text { sawdust }\end{array}$ & 11.76 & 1.84 & 19.02 & 5 \\
\hline
\end{tabular}

a. $p H$

From the water quality experimental program upon curing water, the $\mathrm{pH}$ values for all specimens were between 10.0 and 12.0 which is in alkali range. According to Portland Cement Association, alkaline condition will provide extra protection to reinforcement bar while acidic environment will increase the rate of corrosion process in steel [19]. In an alkali environment, a thin layer of oxide is formed on the steel surface and eventually avoid the metal atom from dissolving. However, the result shows that the leachate from the concrete is categorized in Class $\mathrm{V}$ of $\mathrm{pH}$, although it provides extra protection to the reinforcement bar. The comparisons are shown in Figure 5.

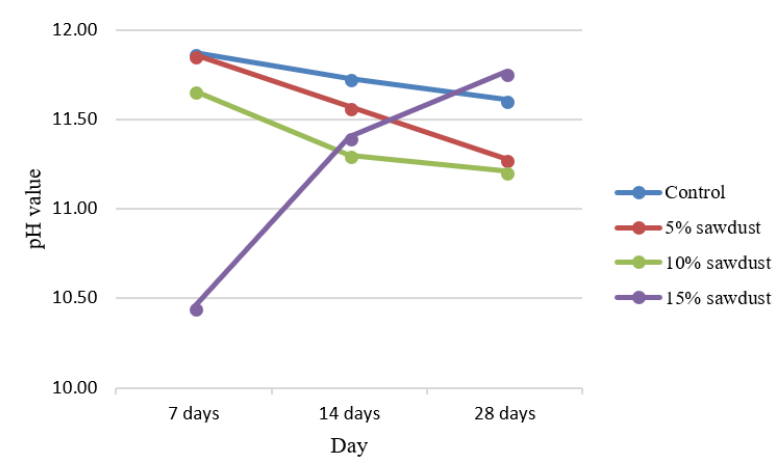

Fig. 5. $\mathrm{pH}$ value of curing water for all concrete mixes

\section{b. Dissolved oxygen (DO)}

DO is vital for the existence of organism whereby higher DO value indicates higher amount of oxygen in the solution [20]. The DO value of control concrete increased as time increased. This is shows that there is reducing in organism in curing water. However, the dissolved oxygen of concrete with sawdust replacement decreased as time increased. This clearly shows that concrete with sawdust replacement is contaminated with organisms and not suitable for the purpose of pool construction and fish pond as which the organisms may harmful to aquatic life and can affect the fish population. In addition, control concrete also follows the standard range which is $5.24 \mathrm{mg} / 1$ to $6.53 \mathrm{mg} / \mathrm{l}$. While the DO values of $5 \%, 10 \%$ and $15 \%$ sawdust ranging from $1.77 \mathrm{mg} / \mathrm{l}$ to $4.34 \mathrm{mg} / \mathrm{l}$ which is lesser than the Water Quality Standard for Class II (5.0-7.0 mg/l) as shown in Figure 6. 


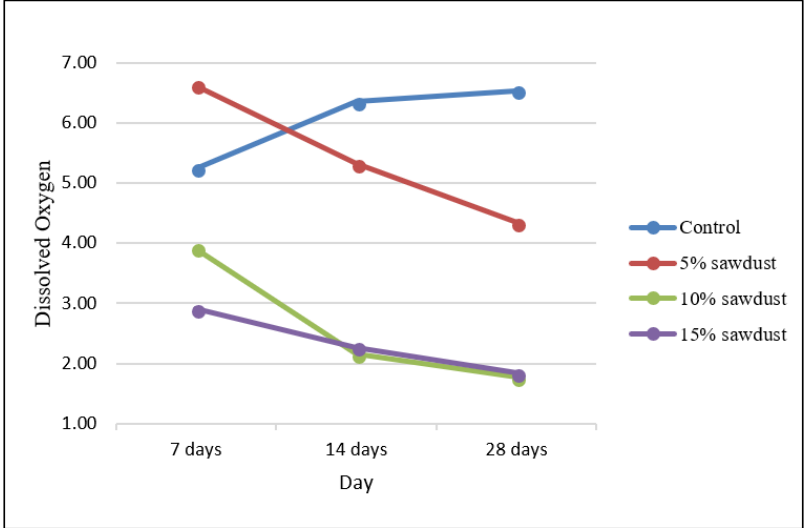

Fig.6. Dissolved oxygen of curing water for all concrete mixes

\section{c. Biological oxygen demand (BOD)}

The BOD value of curing water for all sawdust specimens are shown in Figure 7 which is between $8.67 \mathrm{mg} / \mathrm{l}$ to $19.02 \mathrm{mg} / \mathrm{l}$. As compared to the water quality standard, 5\% sawdust replacement has a lower BOD which is $8.67 \mathrm{mg} / \mathrm{l}$. It can be classified as water quality Class III. However other sawdust concrete the BOD values exceeded the water quality Class IV which not suitable to be used for fishery life but can be used for the irrigation purpose. Furthermore, the BOD value of all of the sawdust replacement increased as the time increased. This shows that more organisms are likely to produce as the time progressed. However, the reading for control cube decrease from 7,14 and 28 days due to less oxygen consumed by the organism as the number of organism decreased as time increased [21].

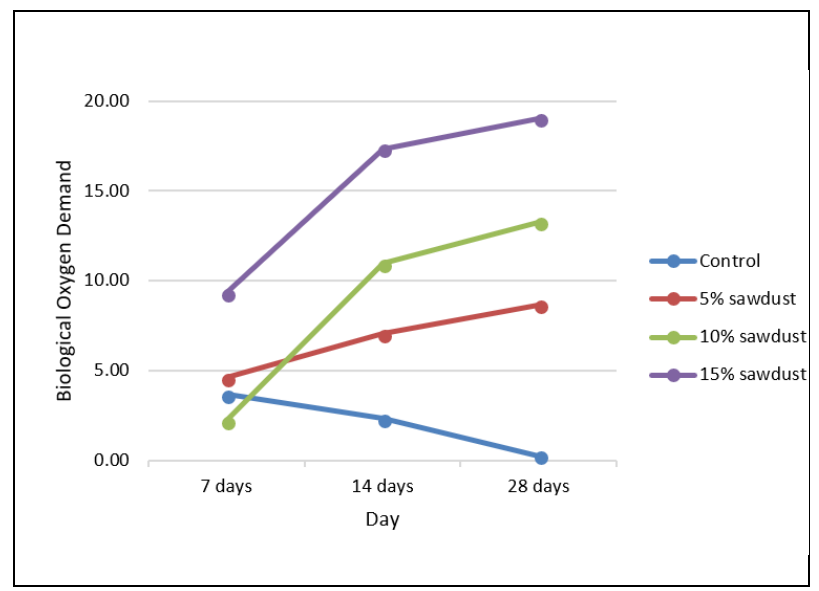

Fig. 7. Biological oxygen demand of curing water for all concrete mixes

\section{d. Chemical oxygen demand}

The COD values shown in Figure 8 are in the range of $-23 \mathrm{mg} / 1$ to $59 \mathrm{mg} / \mathrm{l}$. The COD vial used is Low Range (LR) which supposed to give reading between $0 \mathrm{mg} / 1$ to $150 \mathrm{mg} / \mathrm{l}$ [22]. This clearly shows that COD test is not applicable for this type of leachate. In addition, the Water Quality Standard proposed value is $25 \mathrm{mg} / 1$ and based on the results, there is no value that matches with the standard.

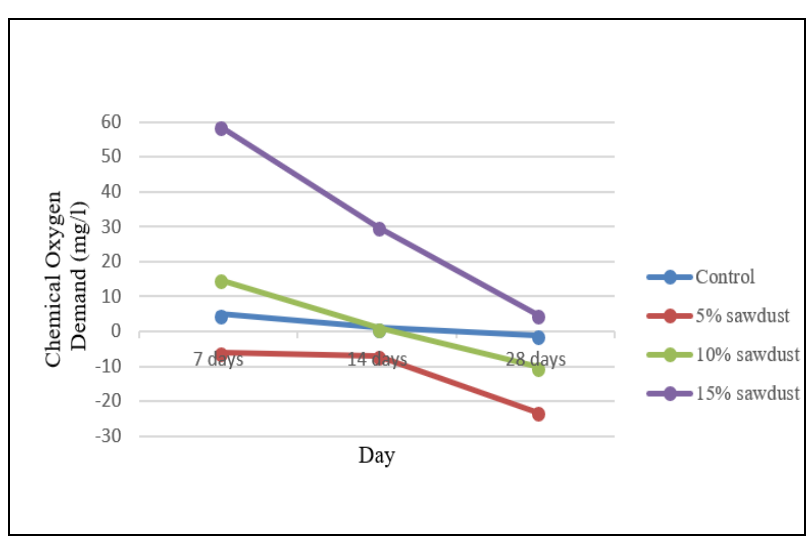

Fig. 8. Chemical oxygen demand of curing water for all concrete mixes

\section{Analysis and Conclusion}

The results of BOD are chosen to be analyze instead of COD, $\mathrm{pH}$ and DO because it is the vital parameter in determining whether the sample is safe to be used in the environmental conditions [23]. Figure 9 shows the analysis of results of compressive strength and BOD for all sawdust concrete replacement at 28 days.

From the analysis, it is found that value of BOD increased when the amount of sawdust replacement was increased. While, the compressive strength decreased when the amount of sawdust replacement increased. From this analysis, the most performed sawdust concrete is the replacement with $5 \%$ which the experimental results prove that the strength is higher compared to other two sawdust concrete mix. A positive result also found in BOD value for $5 \%$ sawdust replacement concrete which the value is lower compared to other two sawdust concrete mixes.

Therefore, the sawdust concrete mix with 5\% replacement is the optimum design that can be adopted and followed for further investigation.

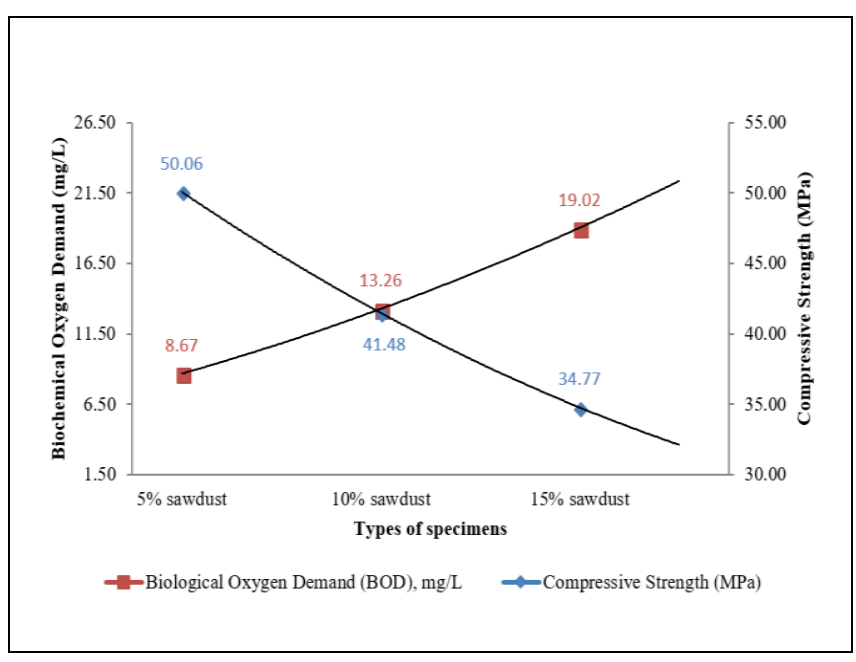

Fig. 9. BOD \& compressive strength versus types of specimens 


\section{References}

1. Josh Gabbatiss Sands mafias and vanishing islands: How the world is dealing with the global sand shortage. Science Correspondent. (2017).

2. Marcus Fairs. Sand becomes increasingly scarce and expensive. threatening glassmaking and construction. 11 October 2017, (2017)

3. The conversation (2017). The world is facing a global sand crisis. The conversation Academic Rigorous, Journalistic flair. (2017)

4. Mageswari \& B. Vidivelli (2009). The use of sawdust ash as fine aggregate replacement in concrete. Journal of Environmental Res. Dev. 3(3) 720-726 (2009)

5. MIDA. 'Manufacturing Wood Industry'. Malaysian Investment Development Authority. Available from http://www.mida.gov.my/home/wood-industries/posts/ (Accessed on 30 April 2018)

6. MTIB. National Timber Industry Policy 2009-2020. Ministry of Plantation Industries and Commodities Malaysia. (2009)

7. Shafini Mohd. Shafie Zakirah Othman \& Norsiah Hami (2017). Potential Utilisation Of Wood Residue In Kedah: A Preliminary Study. Journal of Technology and Operations Management - Special Issue, 60-69 (2017)

8. Mateusz Stasiak, Marek Molenda, Maciej Ban' da, Ewa Gondek (2015). Mechanical properties of sawdust and woodchips, Fuel 159, 900-908 (2015)

9. Theodore W. Marotta, John C. Coffey, Cynthia Brown LaFleur \& Christine LaPlante. Basic Construction Materials. Pearson Education Inc. (2011)

10. Eboziegbe PatrickAigbomian \& MiziFan, Development of wood-crete from treated sawdust. Construction and Building Materials Volume 52, 15 February 2014, 353360 (2014).

11. A.S.M. Abdul Awal, A.A. K Mariyana \& M. Z. Hossain (2016). Some Aspects of Physical And Mechanical Properties Of Sawdust Concrete. International Journal of GEOMATE, 10, Issue 21, 1918-1923, (2016)

12. Ruhal Pervez Memon, Abdul Rahman Mohd. Sam, A. S. M. Abdul Awal \& Lemar Achekza (2017). Mechanical And Thermal Properties Of Sawdust Concrete. Journal Teknologi 79, 23-27, (2017)

13. Maggi Madrid, Aimar Orbe, Hélène Carré \& Yokasta García (2018). Thermal performance of sawdust and limemud concrete masonry units. Construction and Building Materials 169, 113-123, (2018)

14. Ministry of the Environment (2018). Interim national water quality standards for Malaysia.Available from www.wepadb.net/policies/law/malaysia/eq_std. htm (Accessed on May 15 2018)

15. D.C. Teychenne, R.E. Franklin \& H.C. Erntroy. Design of Normal Concrete Mixes. Department of the Environment. (1992)

16. Paramasivam, P., \& Loke, Y.. Study of sawdust concrete. The International Journal of Lightweight Concrete, 57-61, (1980)

17. Ravindrarajah R. S., Carroll C. \& Appleyard N. Development of sawdust concrete for block making. Construction Technology 2011 Conference, 202-210, (2001)

18. Ganiron, T. U.. Effect of Sawdust as Fine Aggregate in Concrete Mixture for Building Construction. International Journal of Advanced Science and Technology, 73-82, (2014)

19. Portland Cement Association. Types and Causes of Concrete Deterioration. Illinois: Portland Cement Association. (2002)
20. Salvato, J. A., Nemerow, N. L., \& Agardy, F. J. Environmental Engineering. New Jersey: John Wiley \& Sons Inc. , (2003)

21. Dhawan, A., \& Karu, S. Effect on Water Quality Pond Productivity and Growth of Carps In Poly Culture System. The International Centre for Living Aquatic Resources Management, 1-14, (2002)

22. Boyles, W. The Science of Chemical Oxygen Demand. Technical Information Series, (1997).

23. Ogunrinde, Y. O., \& Ehiagbonare, J. E. Physio-Chemical Analysis of Fish Pond Water in Okada and Its Environs, Nigeria. African Journal of Biotechnology, 5922-5928, (2010) 